\title{
Fatal Infectious Epidemics in Iran in the Last Two Centuries; What Lessons Can We Learn from Preceding Outbreaks? A Brief Historical Review
}

\author{
Mohammad Hossein Azizi, MD ${ }^{1 *}$; Farzaneh Azizi, DVM² \\ ${ }^{1}$ Academy of Medical Sciences of the I.R. of Iran, Tehran, Iran \\ ${ }^{2}$ Department of Radiology, Iranian Veterinary Hospital, Tehran, Iran
}

\begin{abstract}
In the past two centuries, several fatal infectious outbreaks have arisen in Iran. Presented here is a brief historical account of four fatal epidemics including cholera, plague, Spanish influenza of 1918 and smallpox between1796 and 1979. The lessons from these outbreaks could be helpful for better combatting other deadly epidemics including the present-day disastrous COVID-19 pandemic.

Keywords: Cholera, Iran, Plague, Smallpox, Spanish influenza of 1918

Cite this article as: Azizi MH, Azizi F. Fatal infectious epidemics in Iran in the last two centuries; what lessons can we learn from preceding outbreaks? A brief historical review. Arch Iran Med. 2020;23(8):578-581. doi: 10.34172/aim.2020.66.
\end{abstract}

Received: June 1, 2020, Accepted: July 2, 2020, ePublished: August 1, 2020

\section{Introduction}

The foremost epidemics in Iran, between 1796 and 1979, were two fatal bacterial infection outbreaks including cholera and plague, along with two viral epidemics of smallpox and the Spanish influenza of 1918. Serious shortage of safe water supply, unsanitary public conditions, World War I, World War II, ignorance about health care and poverty were major contributing factors of recurrent infectious outbreaks during the 19th and the first decades of the 20th century. Their key facilitating factors for spread should be considered. As David S. Jones recently wrote, "The history of epidemics offers considerable advice, but only if people know the history and respond with wisdom". ${ }^{1}$ What lessons can be learned from pervious epidemics in Iran?

\section{Cholera Epidemics}

During the Qajar period (1796-1925), the public health condition in Iran was poor. As an example, in the 19th century, the infant mortality rate, which is now considered as an index for public health assessment, was above $50 \%,{ }^{2}$ whereas simultaneously in France and Germany, this figure was around $20 \% .^{3}$ At that period in Iran, the most widespread documented epidemics accompanied by high mortality were cholera and the plague. ${ }^{4}$ Historically, between 1820 and 1903, seven major cholera outbreaks took place in Iran as part of the pandemics. ${ }^{2,5}$

Why did cholera hit Iran so hard? Multiple factors were responsible including:

\section{A. Iran and the Neighboring Countries}

On that occasion, Iran was potentially at danger of recurrent cholera outbreaks from her neighboring countries. Close relations with Afghanistan and Iraq, as well as the transmarine trade with India on the Persian Gulf ports and the commercial relation of the northern Iranian cities with Russia were particularly determining factors. ${ }^{6}$ Moreover, at that time, the Iranian pilgrims' travel to Mecca and Iraq's sacred cities had a major role in transmission and distribution of the infectious diseases. During the 1885 cholera epidemic, Naser ad-Din Shah Qajar ordered the governors to ban pilgrimage to Iraq (Figure 1).

The first, second and third cholera outbreaks appeared in Iran in 1821,1829 and $1846 .{ }^{\circ}$ However, at that time Iran was ill-prepared to cope with public health challenges. Amir Kabir (1807-1852), Prime Minister of Naser al-Din Shah, intended to improve public health and prevent further spread of contagious diseases. So, he ordered application of the quarantine measures at the Iran-Iraq border when a cholera outbreak occurred. After Amir Kabir's dismissal and death, his desired preventive measures including public sanitary education and enforcing quarantine during outbreaks were hindered.? Seemingly, during the outbreaks, most Iranian authorities of the time did not care for public health issues, and isolated themselves in safe places for self-protection, except when they had been pressured by the neighboring governments. ${ }^{10}$ 


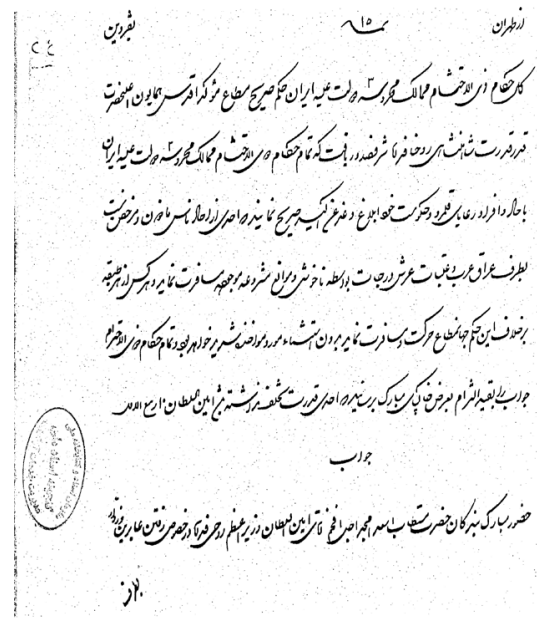

Figure 1. The Order of Naser al-Din Shah to the Governors on Banning of Pilgrimage to the Holy Cities of Iraq Due to an Outbreak of Cholera, 1885. (Source: Medical documents copies, Traditional Library of the Academy of Medical Sciences of Iran).

\section{B. Lack of an Effectual Health Authority}

Even though the first informal health authority, known as the "Council for Preservation of Health" (Majles Hefz-oSehheh) was founded in 1881, it was not functional until 1904. Its activities continued on a limited scale until 1920, when it was named the "Public Health Administration Office". The main mission of the council was to combat fatal infectious epidemics including cholera and the plague (Figure 2). ${ }^{11}$

\section{Famine and Poverty}

In 1851, the fourth cholera outbreak started in Tehran and afterward reached the central parts of Iran. ${ }^{5}$ In 1861, the fifth epidemic arose concurrently with famine which continued until 1871 and public health conditions worsened. The sixth epidemic took place in 1891. Obviously, without adequate economic support, deprived people were more exposed to epidemic diseases and they were defenseless to combat epidemic diseases and death. ${ }^{8}$ So, in the medical literature, cholera is called the "disease of poverty". ${ }^{12}$

\section{Problems Arising from the World War I}

Despite some beneficial efforts in the early decades of the 20th century, cholera outbreaks persisted. The seventh cholera epidemic broke out in 1903. During World War I starting in 1914, Iran was occupied by foreign armies in spite of its declaration of neutrality. The allied forces, the Russian, English and Ottoman troops invaded Iran. War and drought led to severe food shortage. During the war, in 1917, another outbreak of cholera appeared. ${ }^{8}$ The war ended in 1918, but it had a profound impact on Iran's economic, social and health status.

Subsequently, further cholera outbreaks broke out on a limited scale, but some appropriate efforts were made to

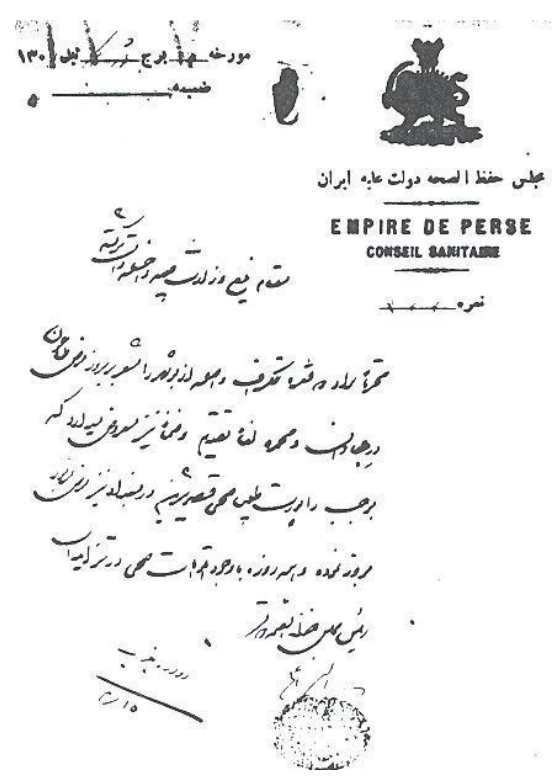

Figure 2. The Iranian "Council for Preservation of Health" to the Ministry of Interior about an Outbreak of a Plague Outbreak in Abadan and Mohammareh (Khorramshahr), Southern Iran as well as in Baghdad, Iraq, 1923. (Source: Medical documents copies, Traditional Library of the Academy of Medical Sciences of Iran) ${ }^{7}$

control the spread of the disease. In 1941, another cholera outbreak appeared in Afghanistan and some quarantine measures were implemented by the Ministry of Health (Vezart-e Behdari) to prevent its further spread into Iran. ${ }^{7,8}$ In 1959, an El Tor subtype of cholera appeared in Pakistan and Afghanistan and reached Iran. However, in 1960, an effective preventive measure was applied by the Pasteur Institute of Iran (established in 1921) and 9.5 million cholera vaccines were made to protect the inhabitants of the eastern regions. ${ }^{13}$

E. Low Level of Budget Allocation for the Public Health According to an official letter in 1916 from the Council for Preservation of Health to the Ministry of Finance (Vezart-e Malieh), an annual budget of 15000 Tomans was allocated for public health affairs and quarantine measures. ${ }^{7}$ In 1927, the "Public Health Administration Office", the forerunner to the future ministry of health, requested the Ministry of Interior to allocate a budget for quarantine stations in northern Iran. The total requested fund was 145000 Tomans. $^{14}$

\section{Human Plague Outbreaks}

There have been multiple human plague epidemics in Iran during the 19th and 20th centuries. For a long time, Kurdistan province in western Iran has been a known endemic area of the human plague. ${ }^{15}$

\section{A. Preventive Measures}

After a plague outbreak in 1877 , the idea of founding quarantine stations was suggested, but their establishment 
was postponed until 1899, when a severe plague outbreak occurred. ${ }^{15}$

Then, in 1905, in the Paris Conference on Quarantine, the establishment of the quarantine stations in southern Iran was suggested to the Iranian officials. ${ }^{8}$ As mentioned previously, the main mission of the Iranian "Council for Preservation of Health" was combatting cholera and the plague (Figure 3).

B. The Role of the Pasteur Institute in Controlling the Human Plague

The founding of the Pasteur of Iran with cooperation of the Pasteur Institute of Paris was a major achievement in controlling infectious diseases and improving public health. In 1926, "vaccination department", "prevention unit" for controlling zoonotic diseases, and several diagnostic medical laboratories for research on endemic diseases were established at the Pasteur Institute of Iran. ${ }^{16}$

In 1937, the Iranian parliament (Majles) allocated an annual budget of 1889960 Rials (around 135000 US dollars) to the Pasteur Institute of Iran (Figure 4). ${ }^{7}$

In 1947, in two villages in Kurdistan, an outbreak of the plague occurred, mostly of the pneumonic type. The Iranian research team of the Pasteur institute headed by Dr. Marcel Baltazard (1908-1971) established an investigation plague center in a village called "Akinlo" in Hamadan Province. The activities of the "Akinlo Research Plague Center" continued for about 20 years and ultimately, Dr. Baltazard and his Iranian colleagues including Dr. Mansour Shamsa (1923-2016) and Dr. Younes Karimi (1929-2009) could find the plague bacilli

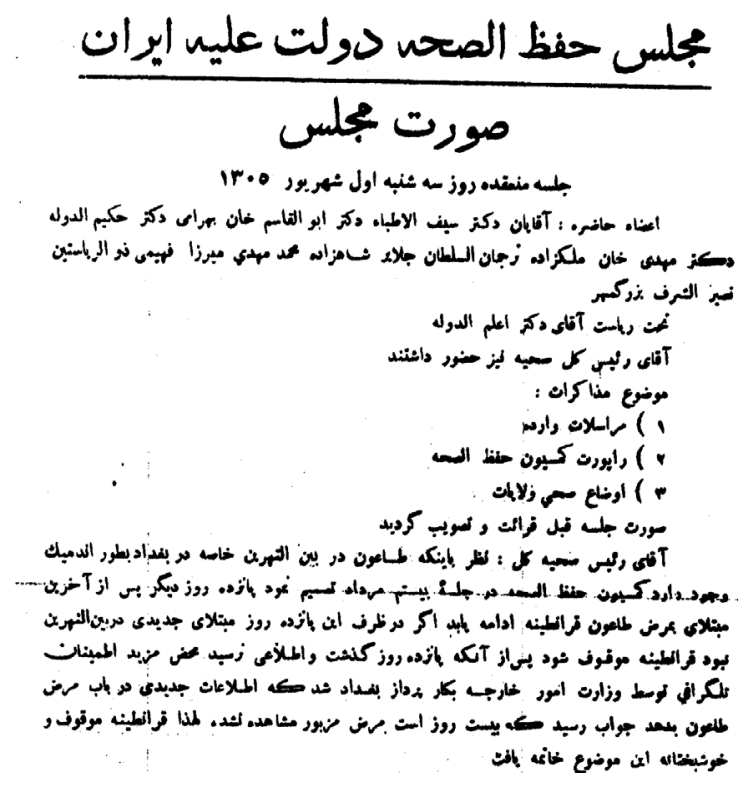

Figure 3. A meeting report of the Iranian "Council for Preservation of Health" (Majles Hefz-o-Sehheh) on a plague outbreak in Baghdad, Iraq, and stopping quarantine after its termination in 1926. (Source: Medical documents copies, Traditional Library of the Academy of Medical Sciences of $\operatorname{Iran})^{7}$ reservoirs in rodents in Kurdistan as well as the natural plague foci in that region. ${ }^{15,17}$

\section{The Spanish Influenza of 1918}

It is estimated that the pandemic of Spanish flu of 1918, subtype $\mathrm{H} 1 \mathrm{~N} 1$, killed around 20-50 million worldwide. ${ }^{18}$ The 1918 Spanish influenza epidemic in Iran occurred in the last year of WWI. In three months in Tehran, the death toll reached $1 \%$ of the total population. At that time, in Shiraz with a population of 50000 , around 5000 people died from the Spanish flu. The death toll in the nomadic Ghashghai tribe was as high as $30 \% .^{2,8}$ According to A.A. Afkhami, during the 1918 Spanish influenza pandemic, the estimated total death toll in Iran was between 902400 and 2431000 , but the real figure was perhaps between these two mentioned extremes. ${ }^{19} \mathrm{~J}$. B. Barry wrote that the Spanish influenza virus killed $7 \%$ of the population of Russia and Iran. ${ }^{20}$ In 1900, Iran had a population of around 9 million. $^{2}$

A. Factors Affecting the 1918 Spanish Influenza Epidemic The WWI complicated the situation. The Russian troops occupied Azarbaijan in north western Iran as well as Ghazvin. The English and their Indian soldiers also invaded Bushehr and Bander-e Lengeh ports in southern Iran. In spreading of the influenza pandemic in the Persian Gulf region, the Indian soldiers in particular had an influential role and the outbreak extended to Bushehr port from India. ${ }^{21}$

At that time, the public health status was poor due to famine as well as a concurrent cholera outbreak, absence of proper medical facilities, inadequate hospitals and shortage of qualified health professionals. ${ }^{4}$ In spite of the fact that the victims of the flu epidemic in the world were mostly young healthy adults, the age pattern was different due to famine, opium addiction, anemia, and malaria. ${ }^{22}$

During the 1918 Spanish flu, no effective public preventive measures were implemented in Iran, while at the same time, in the United States, preventive measures were employed, including in St. Louis State, where

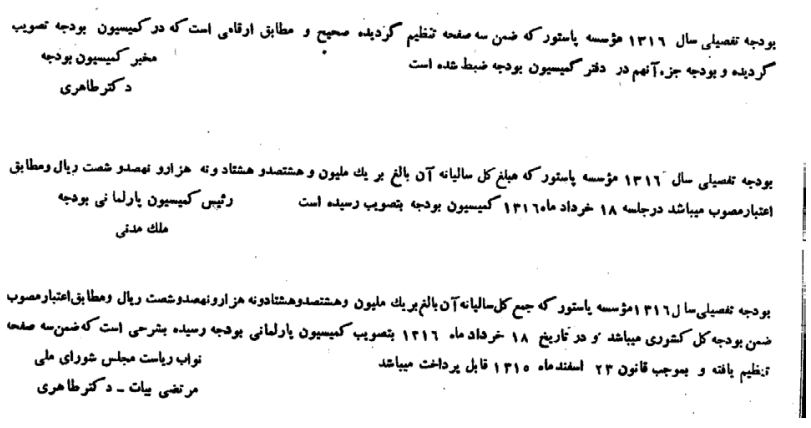

Figure 4. Allocation of Annul Budget by the Parliament (Majles) to the Pasteur Institute of Iran, 1937. (Source: Medical documents copies, Traditional Library of the Academy of Medical Sciences of Iran). 
timely decisions including social distancing, closing the schools, theaters and other public places and banning of gatherings including funerals were effective measures in controlling the epidemic and decreasing mortality as compared to Philadelphia with higher mortality and faster flu spread. In other US cites, the beneficial role of "social distancing" showed in controlling the 1918 pandemic $\mathrm{flu}^{23}$. In addition, throughout the 1918-1919 pandemic flu, decreasing the influenza mortalities in some US cities including San Francisco was partially attributed to the mandatory facial mask wearing. ${ }^{24}$

\section{Smallpox Epidemic and Eradication}

In the nineteenth century, the English physician Dr. John Cormick, the personal physician to Abbas Mirza (17891833), the Iranian Crown Prince, inoculated Abbas Mirza's family as well some people in the villages of Azarbaijan province; however, this was terminated as a result of public resistance. $^{2,25}$

Later, Amir Kabir dispatched small pox care givers to the provinces. In 1848, most children in Tehran were vaccinated. They were not initially accepted by the community, but gradually small pox inoculation became prevalent and many children in major cities were vaccinated. The parents of children who were not vaccinated were charged by the government. ${ }^{?}$

\section{B. Constructive Efforts and Obstacles Which Hampered Smallpox Eradication}

When the Council for Preservation of Health became the main public health authority, they dispatched health officers (Hafez a-Sehheh) to major cities of Iran to promote public health, including performing smallpox vaccination. However, smallpox eradication was not totally popular. In 1880, Naser ad-Din Shah ordered to make the smallpox vaccination mandatory, but it was never applied. Again, between 1898 and 1903, a smallpox outbreak occurred. ${ }^{2}$ Some people did not collaborate with smallpox vaccinators. ${ }^{26} \mathrm{~W}$. Floor wrote that the officials did not consider smallpox to be an important public health threat. Thus, they were not interested in the national vaccination program, even though at that time, the smallpox vaccine was available in the world. ${ }^{2}$

\section{B. A Law to Control Contagious Diseases}

In 1906, the Iranian Parliament (Majles) passed a law to control communicable diseases which included smallpox. Four years later, a budget was allocated for smallpox vaccination program. $^{27}$

\section{Mandatory Vaccination Program}

In 1920, the Council for Preservation of Health was transformed into the Ministry of Health and Charity Affairs (Vezarat-e Sehhyeh va Omur-e Kheiryyeh) and the combat against smallpox continued. ${ }^{28}$ Free of charge smallpox inoculation, from birth until the age of 21 , was considered by the government (Figure 5). Public cooperation for small pox vaccination was initially poor especially, in the rural areas (Figure 6).?

The mandatory vaccination program was approved by the parliament in $1942 .{ }^{27}$

D. The Role of the Pasteur Institute of Iran

According to a report from the Public Health Department of the League of Nations, June-September 1924, the smallpox vaccine production at the Pasteur Institute of



Figure 5. Smallpox Vaccination Program Approved by the Iranian Government in 1932. Free of charge smallpox inoculation, from neonatal period until the age of 21 was considered. (Source: Medical documents copies, Traditional Library of the Academy of Medical Sciences of Iran). ${ }^{7}$

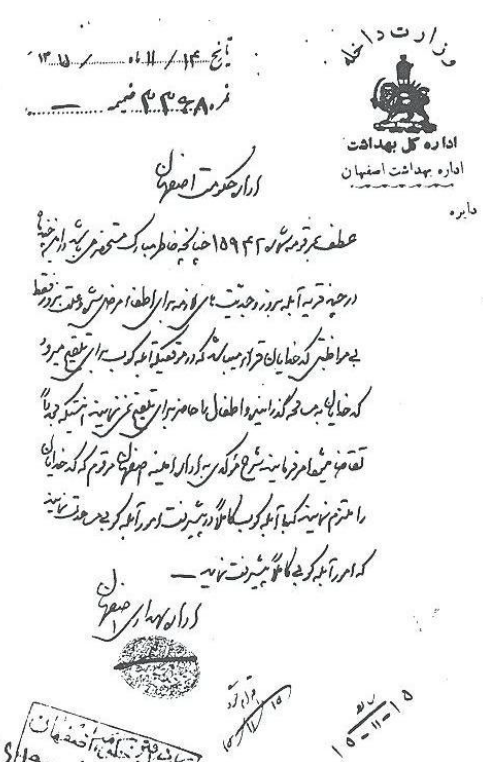

Figure 6. An Official Letter of the Public Health Office of Isfahan to the Ruler, Complaining of Lack of Cooperation of the Village Elders with Smallpox Vaccinators; 1936. (Source: Medical documents copies, Traditional Library of the Academy of Medical Sciences of Iran). ${ }^{7}$ 
Iran reached five million doses in 1928. After WWII, the annual smallpox vaccine production increased to 50 million doses. Before the establishment of the Pasteur Institute of Iran, smallpox vaccine was imported from Paris. The above report added that the main restraining issue for further vaccine production was the unavailability of glass vials. ${ }^{8,14}$

In 1953, the Vaccination Act passed at the Iranian parliament, and the Ministry of Health (Edarey-e Behdasht-e Vezarat-e Behdari) managed the public vaccination program. ${ }^{27}$ Finally, in November 1978, the Iranian Ministry of Health and Welfare reported smallpox eradication in Iran to the World Health Organization, ${ }^{29}$ concurrently with India and around 25 years after smallpox elimination in North America, Europe and Oceania. ${ }^{16}$

What Lessons Can We Learn from Previous Outbreaks? According to a handbook published in 2018 by the World Health Organization, "Will history repeat itself? The answer must be: Yes, it will. A new HIV, a new Ebola, a new plague, a new influenza pandemic are not mere probabilities". The handbook also added that when we encounter epidemics, there are a "range of challenges and real or potential solutions, ranging from the medical and technological to the social and political". ${ }^{30}$

In conclusion, we may learn from prior epidemics that for management of a novel outbreak of infective disease and in order to decrease its morbidity and mortality, launching of timely preventive measures, planned by a well-organized expert team of health professionals and public health policy makers along with official financial and administrative support as well as the national and international collaborations are mandatory. Community participation is important. In addition, continuous public health education is required to avoid misinformation and pseudoscience propagation in the community. Otherwise, the history will repeat itself. This is true of the current COVID-19 pandemic. During epidemics, public health education is essential, because today, 102 years after the Spanish flu and despite significant progress in medical science and increased level of public awareness, we are still witnessing some people following wrong information to prevent and treat COVID-19 or even in some developed countries, resisting quarantine and other preventive measures including social distancing. As mentioned before, based on the historical evidence, during the 1918 pandemic flu in the USA, when there were no effective drugs or vaccines, St. Louis did much better than Philadelphia, because of timely application of preventive measures including "social distancing". ${ }^{23}$

As a recent report showed, during the Ebola virus outbreak in West Africa between 2013 and 2016, in Guinea, Liberia, and Sierra Leone with a death toll of 11323 , many victims were health care workers. ${ }^{31}$ Actually, at the front line of any infectious epidemic combat are health care workers who are at risk of infection with an outbreak pathogen; thus, following the safety occupational measures and availability of required protective equipment are highly suggested. During pandemics, physician burnout is an important issue. In the USA, estimates show that around $\$ 4.6$ billion is the annual cost of physician turnover and reduced clinical hours due to physician burnout. $^{32}$

Strengthening of public health systems and food security, particularly in low income countries, are vital for combatting future pandemics. Last but not least, the profound economic impact of pandemics and the role of poverty and social inequality should not be overlooked. During the current new coronavirus pandemic, on March 27, 2020, the "International Labour Organization" estimated that the rate of unemployment would be 25 million and the workers' income loss will be US $\$ 3.4$ trillion. ${ }^{33}$

\section{Authors' Contribution}

Conceptualization, original draft preparation outlines: MHA. Data searching, preparation: FA, MHA. Writing and editing of final draft: MHA, FA.

\section{Conflict of Interest Disclosures}

None.

\section{Ethical Statement}

Not applicable

\section{Acknowledgements}

The authors wish to thank Farrokh Saidi MD, FACS, FRCS, Touraj Nayernouri MD, FRCS and Farshad Farzadfar MD, MPH for reviewing the manuscript and their valuable comments.

\section{References}

1. Jones DS. History in a Crisis - Lessons for Covid-19. N Engl J Med. 2020;382(18):1681-1683. doi:10.1056/NEJMp2004361.

2. Floor W. Public health in Qajar Iran. Washington DC, USA: Mage Publishers; 2004.

3. Nicholas B, Ballabriga A, Kretchmer N. History of Pediatrics, 1850-1950. New York: Raven Press; 1991.

4. Seyf A. Iran and the Great Plague, 1830-1831. Studia Islamica. 1989;69:151-65.

5. Afkhami AA. Defending the guarded domain: epidemics and the emergence of an international sanitary policy in Iran. Comparative studies of South Asia, Africa and the Middle East. Oficina Sanitaria Pan Americana. 1999;19:122-36.

6. De Planhol X. Cholera. In: Yar Shater E, ed. Encyclopedia Iranica. Available from: http://www.iranica.com. Accessed April 23, 2020.

7. Medical documents copies, Traditional Library of the Academy of Medical Sciences of Iran. Available at the National Library \& Archives of IR of Iran, No. 24000717.

8. Pirnia D, Khansari P, Gozaresh -e, Edareh -ye Sehhyeh Jamea -ye Melal [In Persian], September-June 1924. The Public Health Department of League of Nations. 1976. p.60-62.

9. Adamiyat F. Amir Kabir va Iran [in Persian]. 8th ed. Tehran: Kharazmi Publication. 1999: 332-4.

10. Nategh H.Tasier -e Ejtemai and Eghtesadi Bimari Waba dr Dowreh Ghajar [in Persian]. Tarikh, the supplement of the Journal of Litrature and Humanities College. Vol. 1; 1978.

11. Azizi MH. The historical background of the ministry of health foundation in Iran. Arch Iran Med. 2007;10(1):119-23.

12. Lonappan S, Golecha R, Balakrish Nair G. Contrasts, 
contradictions and control of cholera. Vaccine. 2020;38(Suppl. 1):A4-A6. doi: 10.1016/j.vaccine.2019.08.022

13. Ataei RA, Tavana A, Ghorbani GH. An analysis of recent cholera epidemic in Iran. J Mil Med. 2005;7:49-56.

14. Ghodssi M. The History of the Fifty Years of the Services of the Pasteur Institute of Iran [in Persian]. Tehran: Pasteur Institute of Iran; 1971.

15. Karimi Y. Plague and its Epidemiology [in Persian]. Tehran: Pasteur Institute of Iran; 1977.

16. Danaei G, Farzadfar F, Kelishadi R, Rashidian A, Rouhani OM, Ahmadnia $S$, et al. Iran in transition. Lancet. 2019;393(10184):1984-2005. doi: 10.1016/S01406736(18)33197-0.

17. Mostafavi E, Keypour M. The life and career of Dr. Mansour Shamsa, A pioneer in public health. Arch Iran Med. 2017;20(5):326-328.

18. Krämer A, Kretzschmar $M$, Krickeberg K. Modern Infectious Disease Epidemiology. USA: Springer; 2010:280.

19. Afkhami AA. Influenza. In: Yarshater E, ed. Encyclopedia Iranica. Vol. XIII, Fasc. 2, pp. 140-143. Available from: http:// www.iranica.com/articles/infuenza. Accessed April 23, 2020.

20. Barry JB. The Great Influenza: the Epic Story of the Deadliest Plague in History. USA: Penguin Group; 2004;363.

21. Afkhami AA. Compromised constitutions: the Iranian experience with the 1918 influenza pandemic. Bull Hist Med. 2003;77:367-92.

22. Starr I. Influenza in 1918: Recollections of the Epidemic in Philadelphia Annals of Internal Medicine. Available from: https://annals.org/aim/fullarticle/726088/influenza-1918recollections-epidemic-philadelphia. Accessed April 23, 2020.
23. Smith R. Social measures may control pandemic flu. BMJ. 2007;334(7608):1341. doi: 10.1136/bmj.39255.606713.DB.

24. Strasser BJ, Schlich T. A history of the medical mask and the rise of throwaway culture. Lancet. 2020;396(10243):19-20. doi: 10.1016/S0140-6736(20)31207-1.

25. Ronane CA. Cambridge History of Science. Translated into Persian by Afshar H. 4th ed. Tehran: Nasher-e Markaz; 2005: 564-5.

26. Kasiri $M$, Noraee $M$. Small pox vaccine in Iran: the history and social obstacles. IJME. 2010;3(3):35-43

27. Saadat E. The Progress of Medicine in Iran in Recent Seventy Years [In Persian]. Tehran: Golestan Publication; 1999:154-9.

28. Azizi MH. The historical background of the ministry of health foundation in Iran. Arch Iran Med. 2007;10(1):119-23.

29. Rezai P. Smallpox Eradication in Iran; Report of the Global Commission for the Certification of Smallpox Eradication. General Department of the Communicable Disease, Ministry of Health and Welfare, Tehran, Iran; November 1978.

30. Managing epidemics: key facts about major deadly diseases. Luxembourg: World Health Organization; 2018.

31. Coltart CEM, Lindsey B, Ghinai I, Johnson AM, Heymann DL. The Ebola outbreak, 2013-2016: old lessons for new epidemics. Philos Trans R Soc Lond B Biol Sci. 2017;372(1721):20160297. doi: 10.1098/rstb.2016.0297.

32. Han S, Shanafelt TD, Sinsky CA. Estimating the attributable cost of physician burnout in the United States. Ann Intern Med 2019; 170:784-90.32.

33. COVID-19 has exposed the fragility of our economies. Available from: https://www.ilo.org/global/about-the-ilo/ newsroom/news/WCMS_739961/lang--en/index.htm. Accessed May 9, 2020. 